\title{
Do Student Volunteers Benefit from Community Engagement?
}

\author{
Doris Padmini Selvaratnam ${ }^{1}$ \\ ${ }^{1}$ School of Economics, Faculty of Economics and Management, Universiti Kebangsaan Malaysia, Bangi, \\ Malaysia \\ Correspondence: Doris Padmini Selvaratnam, School of Economics, Faculty of Economics and Management, \\ Universiti Kebangsaan Malaysia, 43600 Bangi, Selangor, Malaysia. Tel: 60-3-8921-5775. E-mail: \\ pegasus@ukm.my
}

\author{
Received: March 7, 2013 Accepted: March 29, 2013 Online Published: April 25, 2013 \\ doi:10.5539/ass.v9n8p123 URL: http://dx.doi.org/10.5539/ass.v9n8p123
}

\begin{abstract}
Community engagement is enriching and empowering for the recipient or host community. There is transfer of knowledge and sometimes economic or social benefits. While a lot of research has been conducted to assess the benefits of community engagement to the host community, little progress has covered the implications for the students participating in university community engagement. This paper discusses the findings of community engagement programme in Orang Asli Settlement in Kuala Gandah, Pahang. The objective of the research is to investigate the impact of community engagement programme to the student participants who were enrolled in Economics of Social Policy course at the postgraduate masters' level. Students' response to their level of academic performance, life skills, civic and social responsibility and personal development was assessed with a pre and post test questionnaire. Their response was based on the Likert scale of 1-10. Results were tabled and calculated for percent increase in knowledge based on the gap analysis method.
\end{abstract}

Keywords: university social responsibility, community engagement, social skills

\section{Introduction}

Universities today face a challenge of producing graduates with academic excellence and also supplemented with social skills. These skills are essential as the work environment has changed dramatically to include a global workforce with diverse cultural background (Tan, 2012). According to Professor Tan Tai Yong, the "... graduates of today and the future will work in a multi cultural background and environment, furthermore, rapid advancement of technology, workplace will change tremendously." Universiti Kebangsaan Malaysia is fortunate to have a deputy vice-chancellor for university-industry-community partnerships. This portfolio reflects the university's commitment to plan, organise and implement community and industry linked programmes for the students' participation. The portfolio also opens opportunities for transfer of knowledge and technology from the university experts to community and industry, encouraging social capital enrichment through courses, workshops and skills development. Working with other agencies and organisations outside the university also opens opportunity for capacity building and institutional development. The university acknowledges the importance of courses that includes laboratory or community service as part of course evaluation method, as it helps to create holistic students who are evaluated not merely on classroom activities or examinations.

Researches of community engagement in the $70 \mathrm{~s}$ and 80 have highlighted the benefits towards the host community. More recently, when universities began to highlight the importance of university social responsibility, the challenge also began to shift towards creating holistic graduates. Students do not merely exhibit academic excellence, but are also expected to exhibit leadership skills, ability to work in a team, communication skills in a diverse cultural setting, source for funds and also make community programme proposals. According to Hedin (1989) students experience cognitive gains from reflections on their own experiences during community engagement. Carini. et. al. (2006) studied the relationship between student engagement with experimental and traditional measures of academic performance. Their findings show that students with lowest ability benefit more from community engagement. It is possible that students that have lower academic performance make up with social skills. Handelsman, et. Al. (2005) study on college student engagement in Australia show that there are four 'dimensions of college student engagement that were distinct and reliable: skills engagement, participation/interaction engagement, emotional engagement, and performance engagement.' 


\section{Course Based Community Engagement}

The community engagement program was first established in 2001 as part of Economics of Social Policy (EPPE6154) graduate course assessment component. Then it was introduced for assessment in two other undergraduate courses, namely, Social and Political aspects of Development (EPPE2333) and Economics of Social Policy (EPPE2523) while the ultimate aim of the program is to enhance the quality of life of the Orang Asli in Malaysia via the socioeconomic indicators, it has also the objective of creating students who are caring for fellow members society who are disadvantaged/displaced. Enabling students to work in a group to organise activities, create scheduled timelines of aims/goals for community development. Students also learn to source for finding/donations from individuals, private organisations, etc for corporate social responsibility initiatives. Students also keep a journal of their activities and keep track of past initiatives/classroom learnt theories, examples, etc for improve the programme outcomes.

Students identify the location of the community engagement. As there are many Orang Asli settlements, the students focus on the Orang Asli Che Wong tribe settled in Kuala Gandah, in the state of Pahang. Contact with the local community leaders are important to assess the needs of its members, officers from Orang Asli Development Department and the leaders from the Orang Asli community, known as the Tok Batin are gathered together to gather information. And informal gathering is held to collect data which is then used to formulate activities for the Orang Asli. The general sanitary condition of the dwelling is not satisfactory and there is a lack of concern over their personal hygiene. Most of the Orang Asli are either still involved in jungle foliage activities or as menial workers with low paid jobs with an educational background of minimum primary schooling while enhanced education can help open opportunities of better paid jobs, improved personal hygiene and clean environment can help reduce spread of diseases and curb illnesses.

At the faculty level, Faculty of Economics and Management staff is instrumental in ensuring letters/drafts are properly written, while student's assignments and reports are documented and monitored and evaluated for assessment faculty staff also accompany students to visit the community. The faculty is committed to fund students' activities and also course based evaluation programmes. While the faculty continues to fund programmes, the students' own initiative to source private funding is an important process in creating independent students to fund own programs. The faculty also submits progress reports to the Orang Asli Development Department to ensure contact is well maintained and the research output is documented by the department.

The university provides free transport for the students to the Orang Asli settlement and also provides subsidy to cover expenses for the students' meals and accommodations. The faculty also provides a small sum as a token or help for the Orang Asli community. Faculty's meeting and head of departments' meeting (Mesyuarat Ketua-Ketua Bahagian) evaluates the relevance and objectives of the program and advises on the overall budget of the program that has been detailed by the students.

\section{Methodology}

Based on the various activities organised for the Orang Asli, and especially the learning process throughout the semester, the students' response to skill acquisition was assessed. A pre and post-test results based on a Likert scale range of 1 to 10 , with 1 being least desirable/least acquired and score 10 being most desirable/most acquired. A total of 33 students who participated in the community programme answered the test.

\section{Research Findings and Discussion}

The following Figure 1 show the Orang Asli dwelling at Kuala Gandah. 

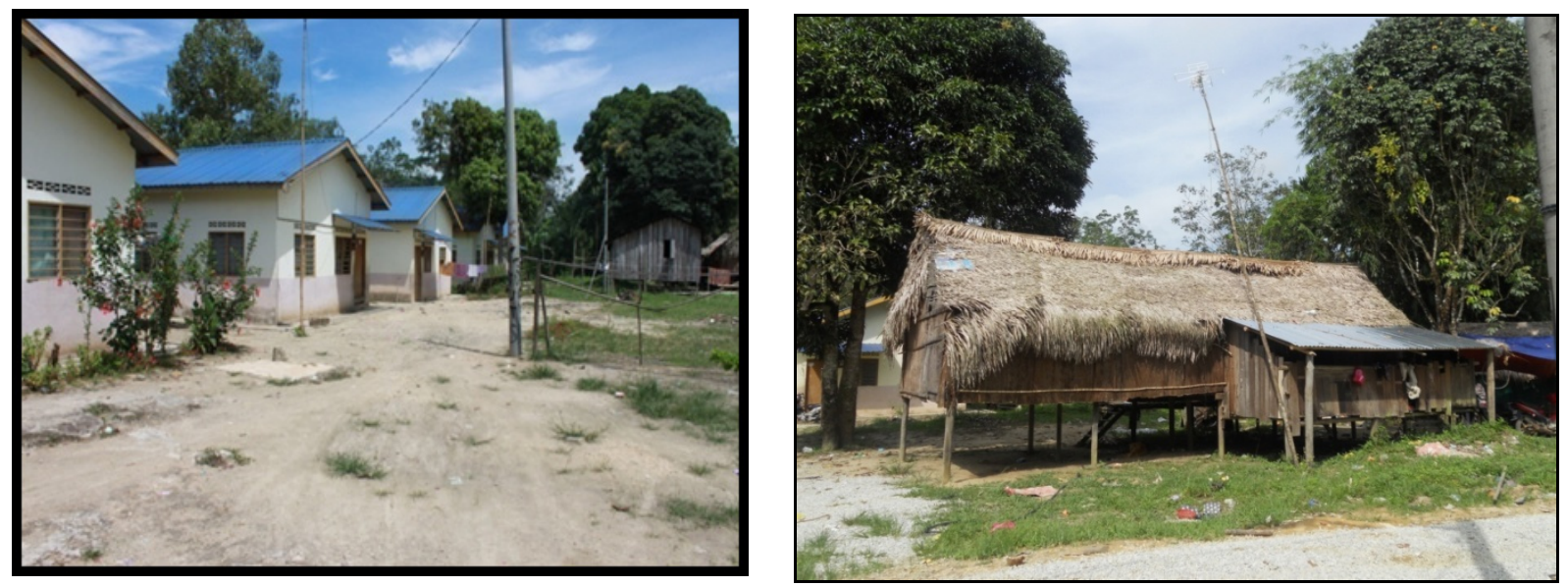

Figure 1. Traditional and modern houses at Kuala Gandah

The figure above shows that the existing modern and traditional houses in parallel reflecting the Orang Asli's day-to-day dwelling in the traditional homes and use of the modern houses to store most of their belongings.

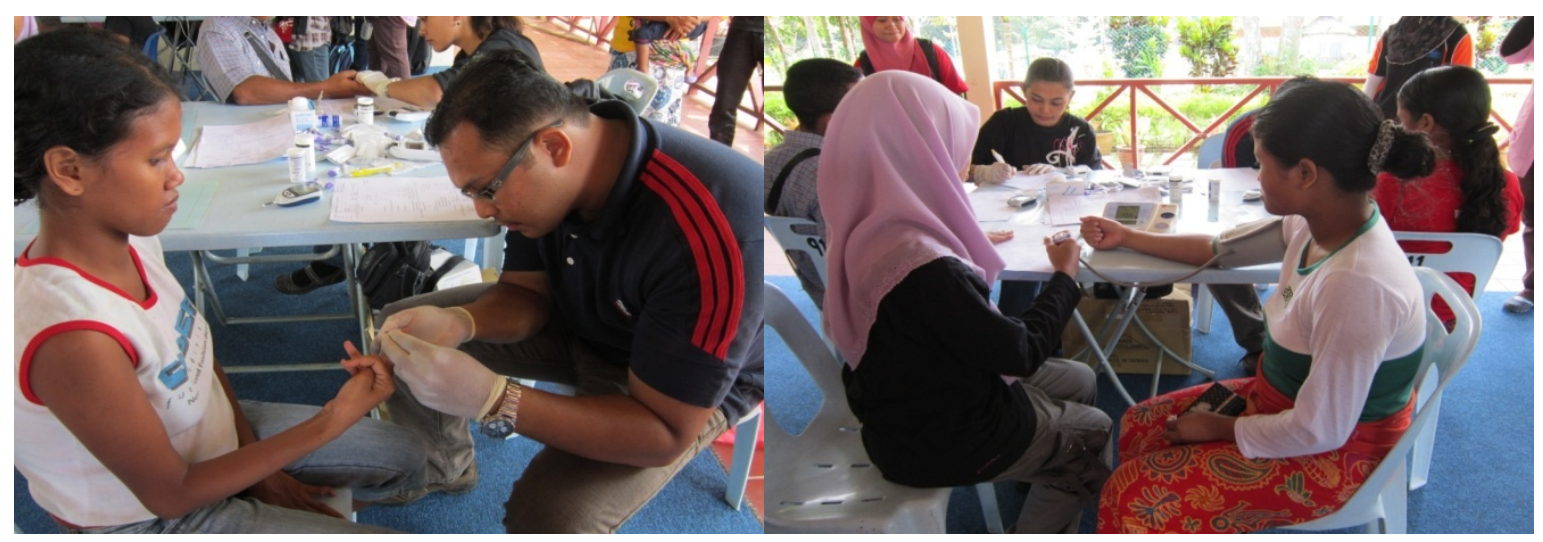

Figure 2. Medical examination by ANGKASA institue UKM staff

Besides conducting Dental Hygiene Awareness talk and demonstration, the basic medical examination, the students also did a demographic survey of the location. The map of the Orang Asli settlement is shown in Figure 3. 


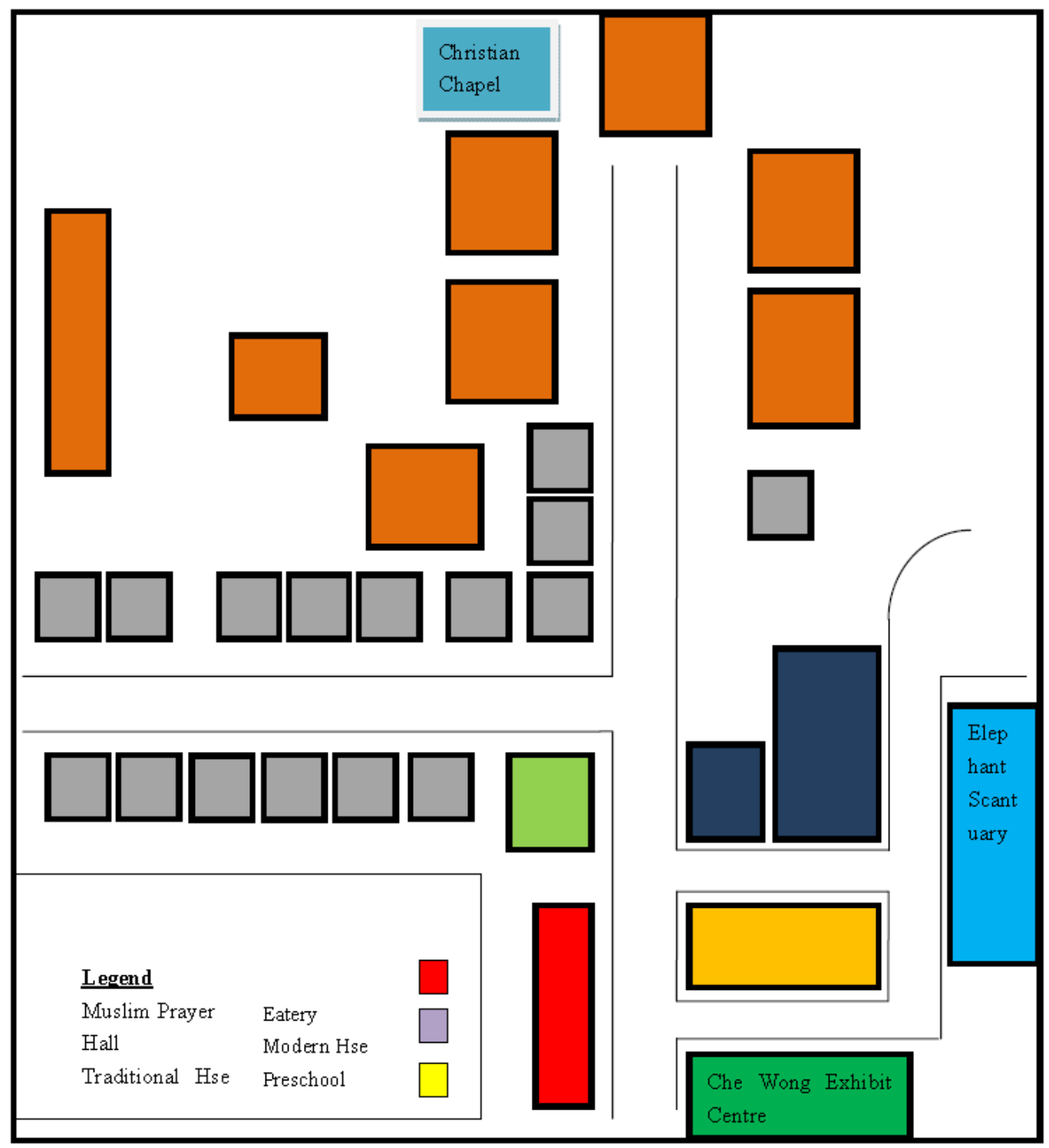

Figure 3. Housing of the Orang Asli Che Wong community, Kuala Gandah Pahang

Source: edited by author from Muhammad Faris Mohd Hanif's drawing in Laporan Penyelidikan Sosioekonomi komuniti Orang Asli Di Kuala Gandah, Lanchang, Pahang.

The pre and post test results was tabulated in SPSS software package and analysed to obtain simple mean scores. The results are shown in Table 1. 
Table 1. Student participants' pre and post test results

\begin{tabular}{|c|c|c|c|c|c|c|c|c|c|}
\hline \multicolumn{5}{|c|}{ Pre Test Results } & \multicolumn{5}{|c|}{ Post Test Results } \\
\hline & Minimum & Maximum & Mean & $\begin{array}{c}\text { Std. } \\
\text { Deviation }\end{array}$ & Minimum & Maximum & Mean & $\begin{array}{c}\text { Std. } \\
\text { Deviation }\end{array}$ & $\begin{array}{c}\text { Gap } \\
\text { Analysis }\end{array}$ \\
\hline $\begin{array}{l}\text { Academic } \\
\text { Performance }\end{array}$ & & & 8.23735 & & & & 8.8182 & & 0.58085 \\
\hline Learning & 5 & 10 & 8.4545 & 1.27698 & 5 & 10 & 9.0303 & 1.10354 & 0.5758 \\
\hline $\begin{array}{l}\text { Cognitive } \\
\text { Process }\end{array}$ & 5 & 10 & 8.0606 & 1.17099 & 6 & 10 & 8.7879 & 0.92728 & 0.7273 \\
\hline $\begin{array}{l}\text { Critical } \\
\text { Thinking }\end{array}$ & 5 & 10 & 8.1212 & 1.34065 & 5 & 10 & 8.697 & 1.10354 & 0.5758 \\
\hline $\begin{array}{c}\text { Persistence \& } \\
\text { Retention }\end{array}$ & 5 & 10 & 8.1818 & 1.26131 & 6 & 10 & 8.697 & 1.01504 & 0.5152 \\
\hline $\begin{array}{c}\text { Achievement \& } \\
\text { Aspirations }\end{array}$ & 5 & 10 & 8.3636 & 1.24545 & 7 & 10 & 8.7879 & 1.05349 & 0.4243 \\
\hline Integration & 5 & 10 & 8.2424 & 1.32359 & 6 & 10 & 8.9091 & 1.15552 & 0.6667 \\
\hline Life Skills & & & 8.4798 & & & & 8.83335 & & 0.35355 \\
\hline $\begin{array}{l}\text { Racial } \\
\text { Tolerance }\end{array}$ & 7 & 10 & 8.6667 & 0.95743 & 7 & 10 & 9 & 0.93541 & 0.3333 \\
\hline $\begin{array}{c}\text { Cultural } \\
\text { Understanding }\end{array}$ & 6 & 10 & 8.7879 & 1.21854 & 7 & 10 & 8.9697 & 0.91804 & 0.1818 \\
\hline Self-Efficacy & 6 & 10 & 8.5152 & 1.12142 & 7 & 10 & 8.7879 & 0.92728 & 0.2727 \\
\hline $\begin{array}{l}\text { Problem } \\
\text { Solving }\end{array}$ & 6 & 10 & 8.3636 & 1.19421 & 6 & 10 & 8.697 & 1.04537 & 0.3334 \\
\hline $\begin{array}{c}\text { Career } \\
\text { Clarification }\end{array}$ & 6 & 10 & 8.3333 & 1.13652 & 7 & 10 & 8.7273 & 1.00849 & 0.394 \\
\hline Leadership & 5 & 10 & 8.2121 & 1.29319 & 7 & 10 & 8.8182 & 1.04447 & 0.6061 \\
\hline $\begin{array}{l}\text { Civic \& Social } \\
\text { Responsibility }\end{array}$ & & & 8.53334 & & & & 9.01212 & & 0.47878 \\
\hline $\begin{array}{l}\text { Commitment } \\
\text { To Community }\end{array}$ & 5 & 10 & 8.697 & 1.15879 & 6 & 10 & 9.0303 & 1.07485 & 0.3333 \\
\hline $\begin{array}{l}\text { Aspiration To } \\
\text { Volunteer }\end{array}$ & 6 & 10 & 8.6364 & 1.19421 & 6 & 10 & 9.1212 & 0.9924 & 0.4848 \\
\hline Empathy & 1 & 10 & 8.3333 & 1.77951 & 1 & 10 & 8.8182 & 1.66686 & 0.4849 \\
\hline Pilanthrophy & 5 & 10 & 8.4848 & 1.25303 & 7 & 10 & 8.9697 & 0.95147 & 0.4849 \\
\hline $\begin{array}{l}\text { Civic-Minded } \\
\text { Professional }\end{array}$ & 5 & 10 & 8.5152 & 1.30195 & 7 & 10 & 9.1212 & 0.85723 & 0.606 \\
\hline $\begin{array}{c}\text { Personal } \\
\text { Development }\end{array}$ & & & 8.5859 & & & & 9.1212 & & 0.535333 \\
\hline $\begin{array}{c}\text { Moral } \\
\text { Development }\end{array}$ & 6 & 10 & 8.6061 & 0.9981 & 7 & 10 & 9.1212 & 0.89294 & 0.5151 \\
\hline Self-Concept & 5 & 10 & 8.4545 & 1.03353 & 8 & 10 & 9.0606 & 0.78817 & 0.6061 \\
\hline $\begin{array}{l}\text { Motives, } \\
\text { Attitudes \& } \\
\text { Values }\end{array}$ & 6 & 10 & 8.697 & 0.98377 & 7 & 10 & 9.1818 & 0.91701 & 0.4848 \\
\hline
\end{tabular}

Note: Gap Analysis $=$ Post Test Results minus Pre Test Results.

Source: Field Survey 
The Table 1 shows that the students post test results showed an increase in the level of academic performance, life skills, civic \& social responsibility and personal development. The highest performance enhancement based on the Gap Analysis method was for academic performance and the least increased enhancement was for the life skills. This is probably due to the fact that the contact hours at the Orang Asli was limited to a day's activity.

\section{Conclusion}

The course based community engagement has given an opportunity for the students to get close to the local community and address their basic needs. Students have demonstrated that they are able to organise themselves to form a committee, have scheduled meetings, record their minutes, circulate for updates among sub-committee and steering committee members. They worked well as a team and exhibited their maturity in making informed decision and getting a consensus. They also produced reports on health, education, housing and welfare of the Orang Asli in Kuala Gandah with specific positive recommendations to further enhance the livelihoods of the Orang Asli in the future.

The pre and post test results was useful in determining the level of benefit derived by the students through their participation in the course based community engagement. There was an increase in the level of academic performance, life skills, civic \& social responsibility and personal development of the students. This has helped to prove that course based community engagement programme is successful in enhancing the soft skills of the students to help prepare them for a global, diverse cultural and challenging work environment in the future.

In the future it is hoped that students will have the opportunity to spend several weeks or months at the site of the community engagement programme. A longer duration will help the students to build on their life skills and also other soft skills. On the other hand, for the local community, a longer period of community engagement will help strengthen social networking, create youth leaders and also make the programme sustainable.

\section{Acknowledgements}

The author would like to express gratitude and appreciation to the Faculty of Economics and Management and the Faculty of Social Sciences and Humanities of Universiti Kebangsaan Malaysia, the Orang Asli Development Department and all the relevant stakeholders for the support given to make this community programme a success. A special thanks to the Orang Asli Che Wong community of Kuala Gandah for receiving us and walking hand-in-hand in realising the university social responsibility.

\section{References}

Carini, R. M., Kuh, G. D., \& Klein, S. P. (2006, February). Student Engagement and Student Learning: Testing the Linkages. Research in Higher Education, 47(1), 1-32. Retrieved October 9, 2012, from $\mathrm{http}: / / \mathrm{www} . j$ stor.org/stable/40185882

Handelsman, M. M., Briggs, W. L., Sullivan, N., \& Towler, A. (2005). A Measure of College Student Course Engagement. The Journal of Educational Research, 98(3), 184-191. Retrieved October 9, 2012, from http://www.jstor.org/stable/27548076 http://dx.doi.org/10.3200/JOER.98.3.184-192

Hedin, D. P. (1989). The Power of Community Service. Proceedings of the Academy of Political Science. Caring for America's Children, 37(2), 201-213. Retrieved October 9, 2012, from http://links.jstor.org/sici?sici=0065-0684\%281989\%2937\%3A2\%3C201\%3ATPOCS\%3E2.0.CO\%3B2-7 http://dx.doi.org/10.2307/1173962

Selvaratnam, D. P. (Ed.). (2012). Laporan Penyelidikan Sosioekonomi Komuniti Orang Asli Di Kuala Gandah, Lanchang, Pahang. FEP: UKM Bangi.

Yong, T. T. (2012). Common Trends and Challenges in ASEM at $3^{\text {rd }}$ ASEM Rectors' Conference. University of Groningen, the Netherlands. Retrieved October 25, 2012, from http://bit.ly/RYZnil 